\title{
Norma Bengell, um dossiê fotográfico
}

Carlos Edvardo Pereira'

l Carlos Eduardo Pereira é formado em cinema pela UFF, mestre em música pela UFRJ e doutor em comunicação social pela UFF, com a tese Carnavalização e antropofagia no metacinema de Carlos Reichenbach. Pesquisador e programador de cinema da Cinemateca do Museu de Arte Moderna do Rio de Janeiro, onde também é pianista de filmes mudos. E-mail: cadu l pereira@hotmail.com 
Norma Almeida Pinto Guimarães D’Area Bengell, nascida em 1935 no bairro do Rio Comprido, no Rio de Janeiro, e recentemente falecida (09/10/2013), foi uma das mais importantes personalidades do cinema brasileiro, também com carreira internacional. Atriz, diretora, cantora e produtora passou por diversas fases de nossa cinematografia, desde as chanchadas da Atlântida (O Homem do Sputinik), o Cinema Novo (Os Deuses e os Mortos), o Cinema Marginal (O Anjo Nasceu, Abismu), o cinema de Walter Hugo Khouri (Noite Vazia, O Palácio dos Anjos e Eros, o Deus do Amor), filme produzido na Boca do Lixo por A. P. Galante (Paixão na Praia), até o cinema da retomada (O Guarani). No exterior trabalhou em produções francesas, italianas, espanholas e americanas, interpretando personagens em filmes de diversos gêneros, inclusive terror $(O$ Planeta dos Vampiros) e western spaghetti (Fedra West e Os Cruéis). No filme estadunidense Running out the luck, dirigido por Julien Temple, contracenou com o astro do rock Mick Jagger.

Filha única de um alemão e uma carioca teve uma infância conturbada, vivendo alguns anos na Alemanha com os avós paternos, durante o final da meninice e a adolescência. De volta ao Brasil, começou a trabalhar como modelo e depois como vedete do teatro de revista da Companhia de Carlos Machado. Em 1959, viajou para a Austrália, para cantar com Domenico Modugno, e no seu retorno foi convidada por Carlos Manga para trabalhar em O Homem do Sputinik, seu primeiro trabalho no cinema.

Norma Bengell fez o primeiro nu frontal do cinema brasileiro no filme Os Cafajestes, causando escândalo na época. Por sua atuação no filme premiado com a Palma de Ouro em Cannes, O Pagador de Promessas, recebeu convite para trabalhar na Itália, onde foi atriz de O Mafioso de Alberto Latuada, La Constanza della Ragione de Pasquale Festa Campanile, entre outros. Por seu trabalho no filme do Latuada, recebeu o prêmio David de Donatello de melhor atriz. 
ano 2 número 4

Fora de Quadro

Voltou a filmar no Brasil, em 1964, com Walter Hugo Khouri, no filme Noite Vazia, que concorreu à Palma de Ouro no Festival de Cannes no ano seguinte. Durante as filmagens, ela se casou no set com o ator italiano Gabriele Tinti. Casamento que duraria até o final da década de 1960.

No período da ditadura militar, foi diversas vezes detida pela polícia e sofreu interrogatórios, o que fez com que se exilasse na França, em 1971. País onde também participou de filmes e peças teatrais.

Enquanto atriz, Norma Bengell é uma das poucas profissionais brasileiras que se dedicou majoritariamente ao cinema. Trabalhou também em televisão e no teatro, tanto no Brasil como no exterior, como por exemplo na montagem de Les Paravents de Jean Genet, com direção de Patrice Chereau (1983). No entanto, seus trabalhos no teatro e na televisão são em número bem pequeno, se comparado a sua intensa carreira cinematográfica.

Na televisão foi atriz nas novelas Os Imigrantes e Os adolescentes da TV Bandeirantes e Partido Alto da Rede Globo. Seu último personagem na TV foi a lésbica Deise Coturno da série Toma lá dá cá, da Globo, em 2008.

Foi homenageada no primeiro FESTRIO (Festival Internacional de Cinema, Vídeo e TV do Rio de Janeiro) (1984). Foi jurada da segunda edição do mesmo festival (1985), onde protagonizou uma bombástica discussão pública com a atriz americana Ellen Burstyn (ganhadora do Oscar de Melhor Atriz pelo seu trabalho no filme Alice não mora mais aqui de Martin Scorsese), quando declarou ser "uma grande atriz". No mesmo ano recebeu das mãos de Jack Lang, Ministro da Cultura da França na época, a condecoração de Oficial das Artes e Letras,concedida pelo governo francês.

Como cineasta começou a dirigir curtas metragens em 1980, passando ao longa metragem em 1987, com Eternamente Pagu. Dirigiu um segundo e último longa metragem em 1996, O Guarani, que lhe ocasionou problemas com as prestações de contas e com a opinião público, lhe trazendo muito abor recimento. Seus últimos trabalhos no cinema foram três curtas documentários, produzidos pela Riofilme, sobre três pianistas brasileiras, Guiomar Novaes, Antonietta Rudge e Magda Tagliaferro (2003 e 2004). O que se segue é um dossiê fotográfico de sua carreira no cinema e sua filmografia. 


\section{rebeca}

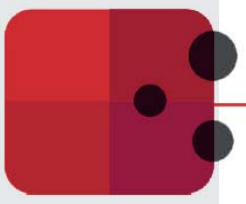

ano 2 número 4

Em uma recepção na embaixada do Brasil em Roma. Na foto vemos também Mercedes La Valle, correspondente da Cazeta de São Paulo, Hugo Sola, presidente do Instituto Cultural Ítalo Brasileiro e

o embaixador do Brasil em Roma, Hugo Couthier.
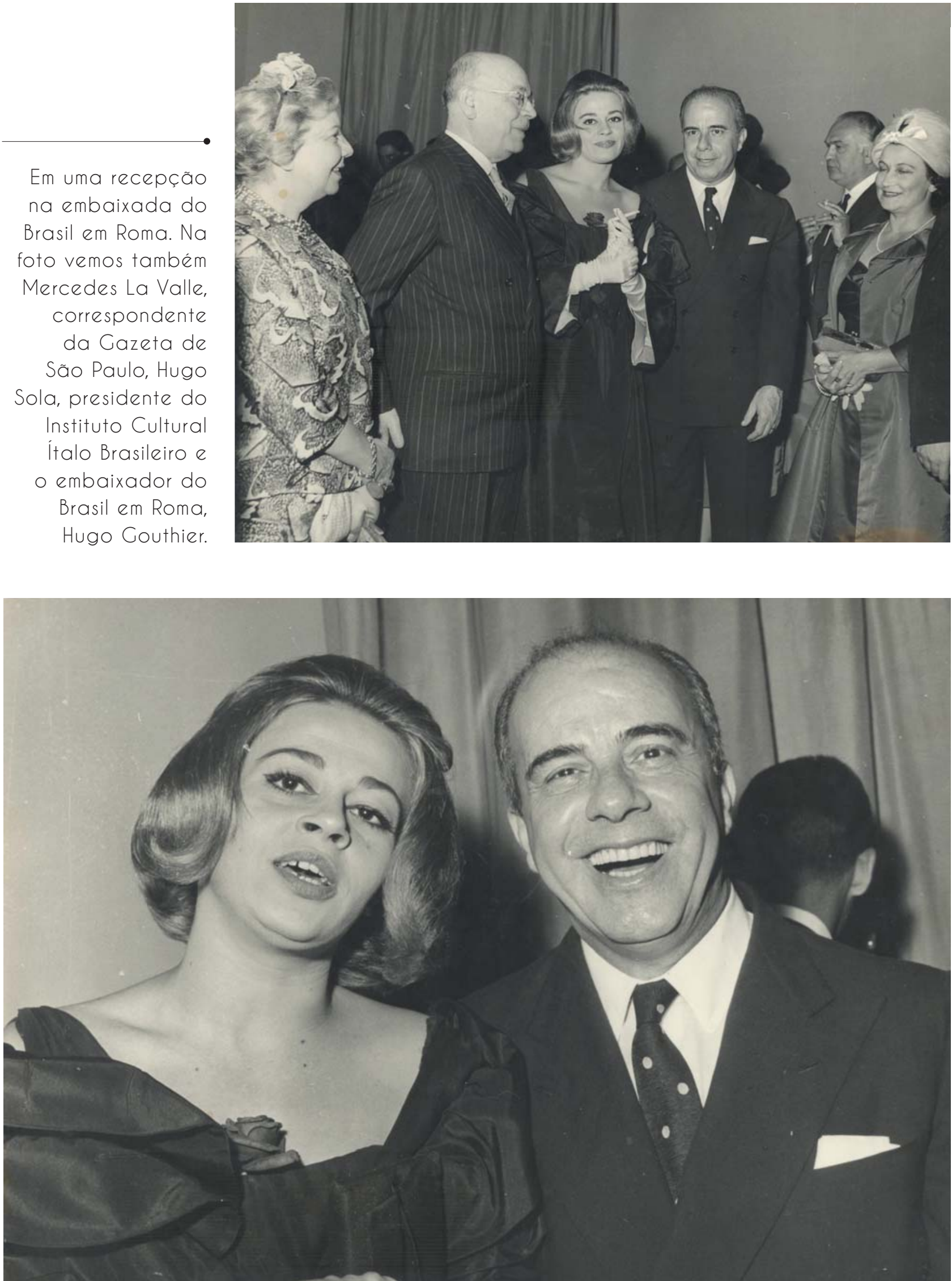

Com Hugo Gouthier, embaixador do Brasil em Roma, em uma recepção na embaixada brasileira na Itália. Com Hugo Gouthier, embaixador do Brasil em Roma, em uma recepção na embaixada brasileira na Itália. 


\section{rebeca}

ano 2 número 4
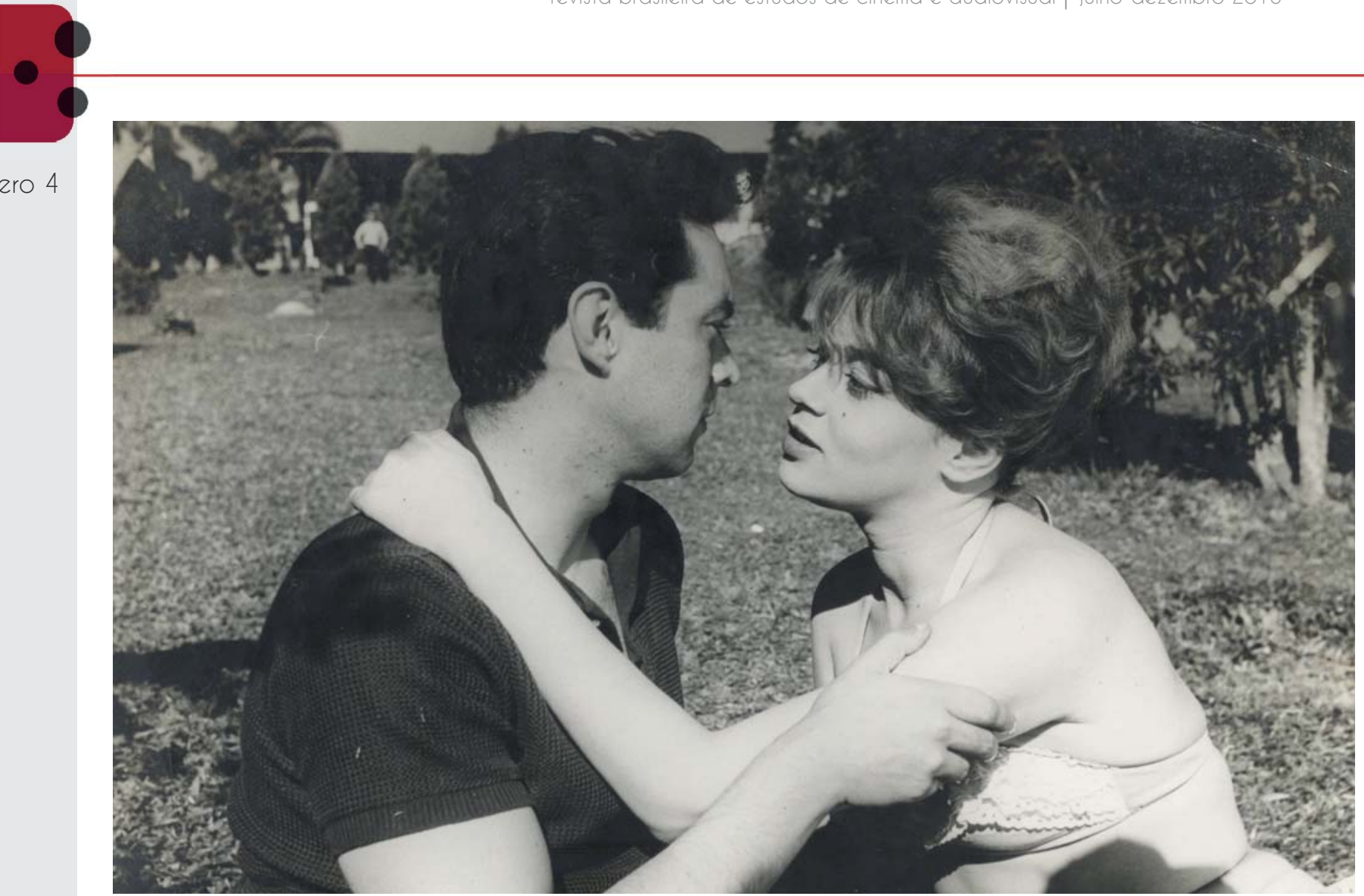

No filme Conceicão, de Hélio Souto (na

foto também como ator), 1960.

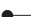

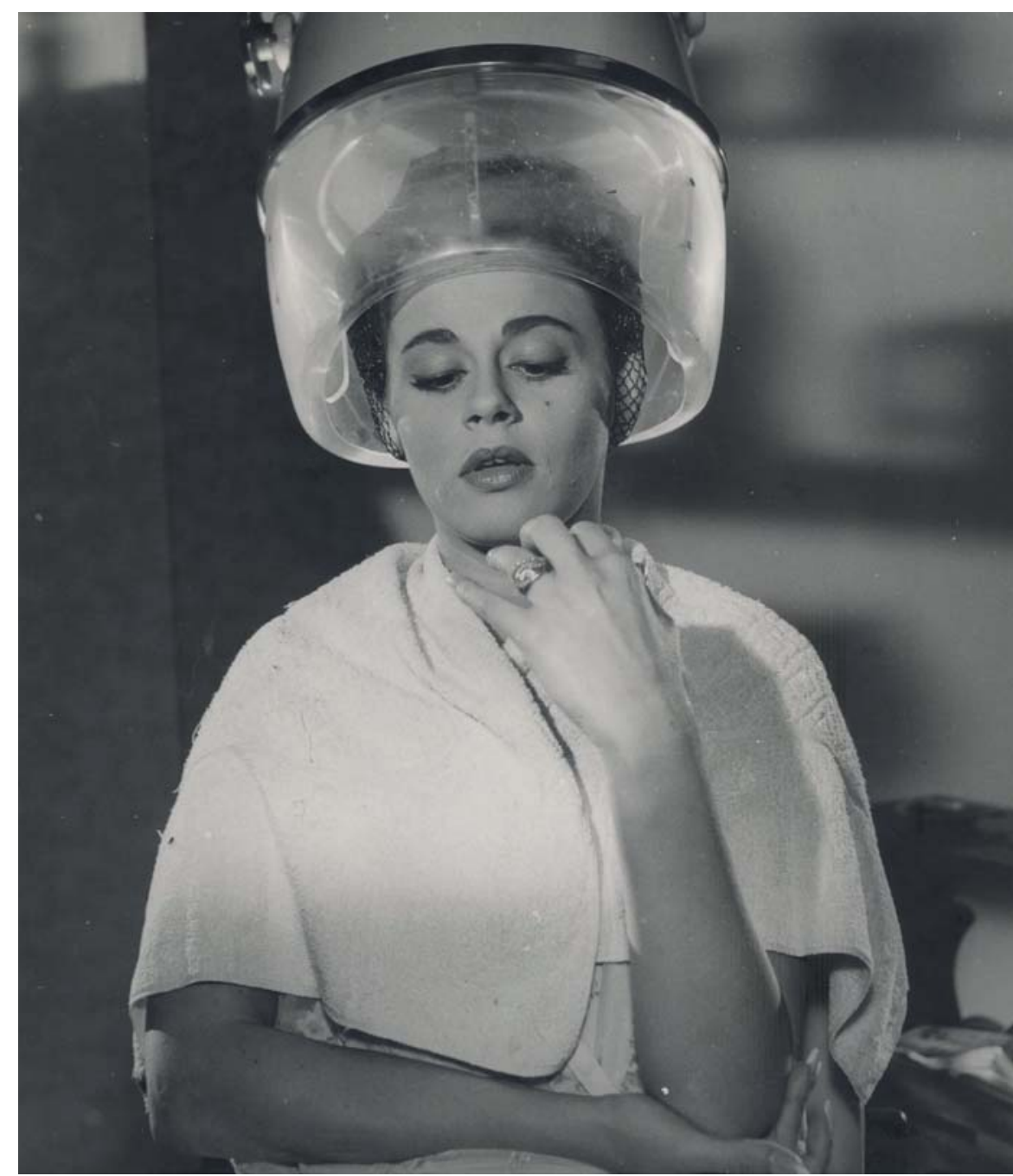




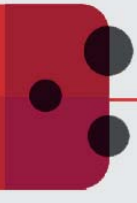

ano 2 número 4

Fora de

Quadro

No filme $O$

Pagador de

Promessas, de

Anselmo Duarte,

1962.
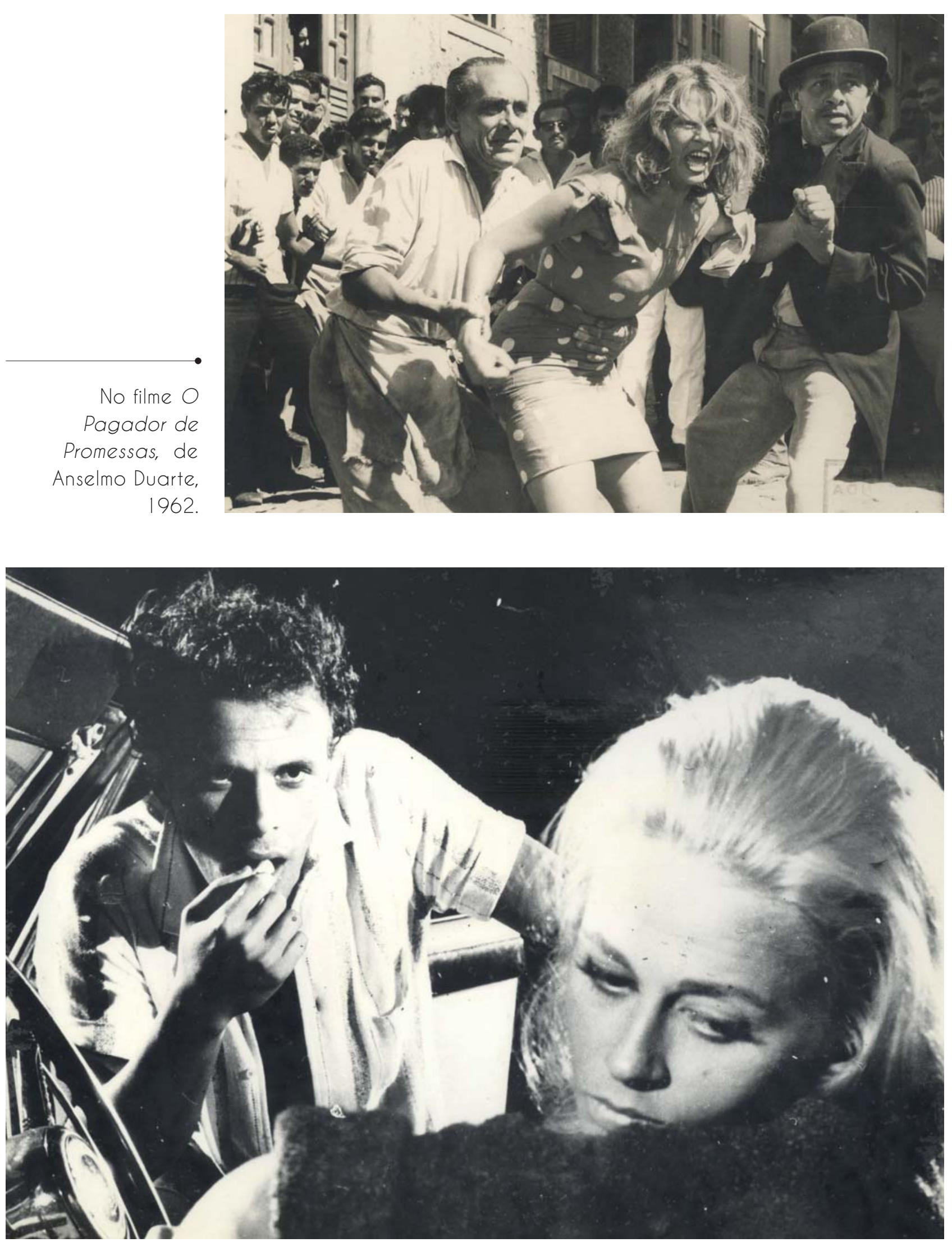

Com Jece Valadão em Os Cafajestes, de Ruy Guerra, 1962. 


\section{rebeca}

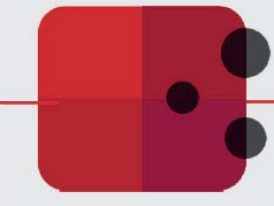

ano 2 número 4

Fora de

Quadro

No filme Edu,

coração

de ouro, de

Domingos de

Oliveira, 1968.
Norma Bengell, um dossiê fotográfico

Carlos Eduardo Pereira
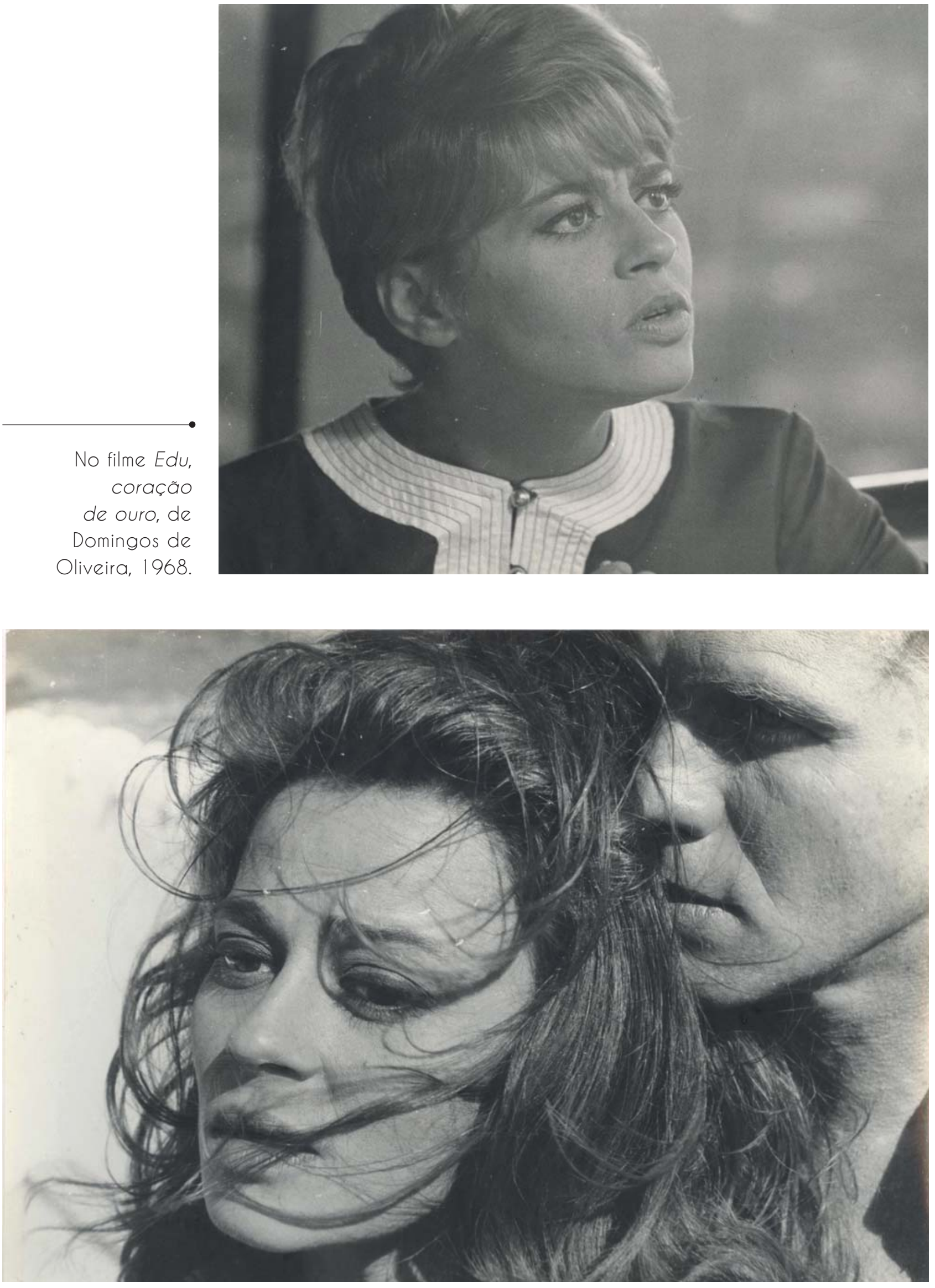

285

Com Jardel Filho em Antes, o verão, de Gerson Tavares, 1968. 


\section{rebeca}

ano 2 número 4
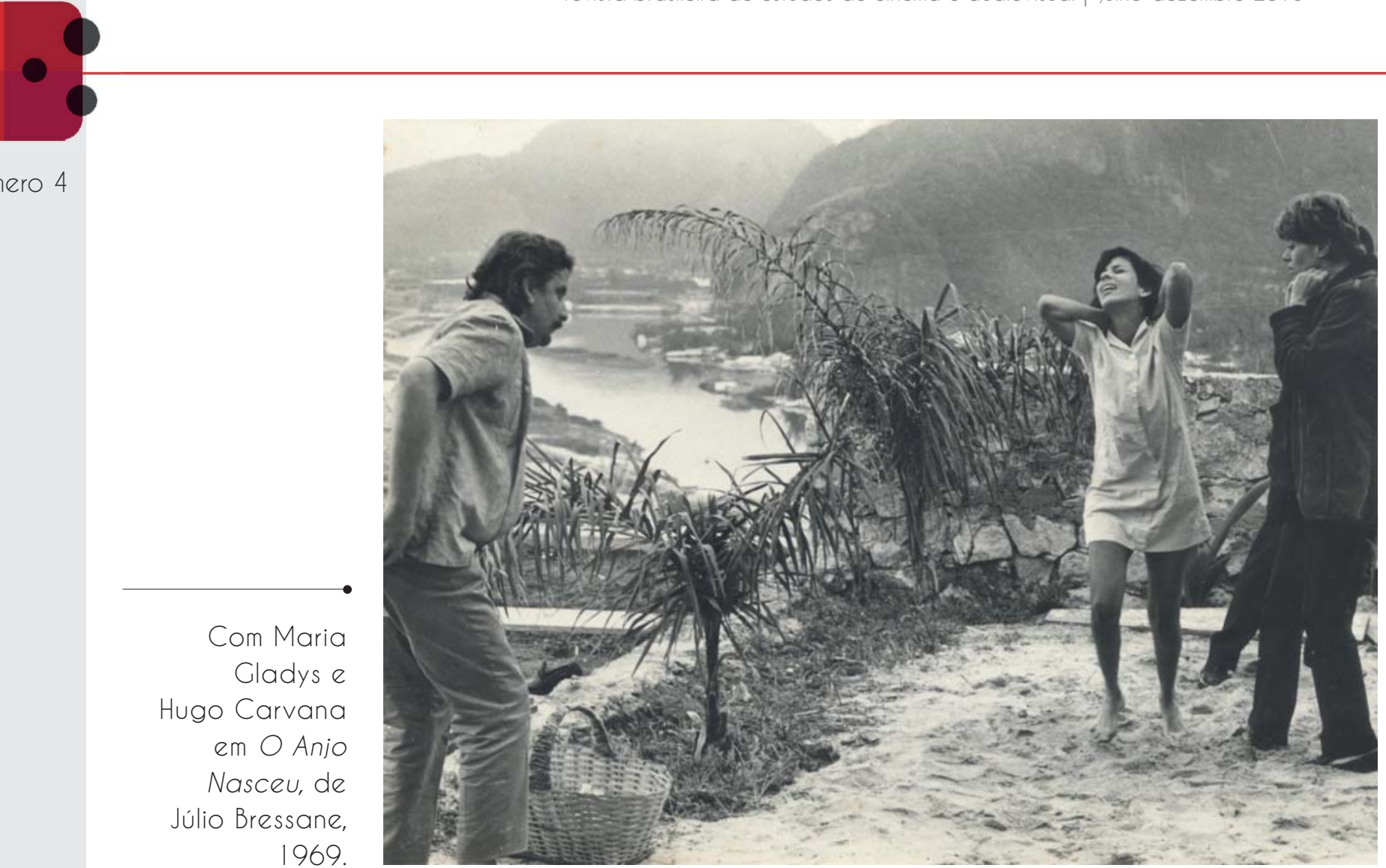

1969

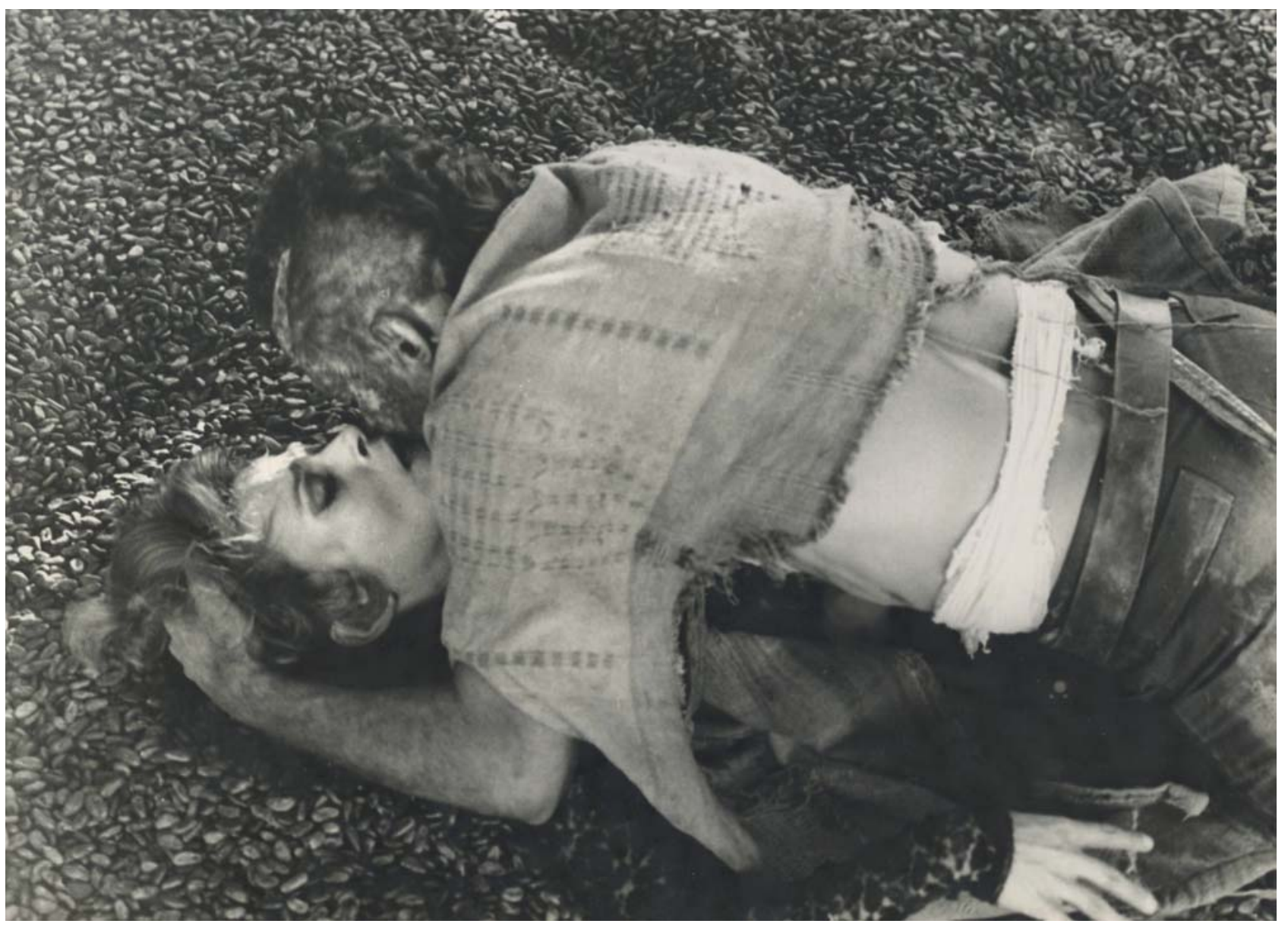




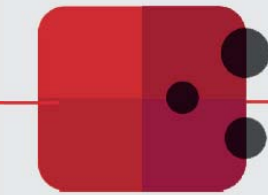

ano 2 número 4

Fora de

Quadro

No filme A Casa Assassinada, de Paulo César Saraceni, 1971.
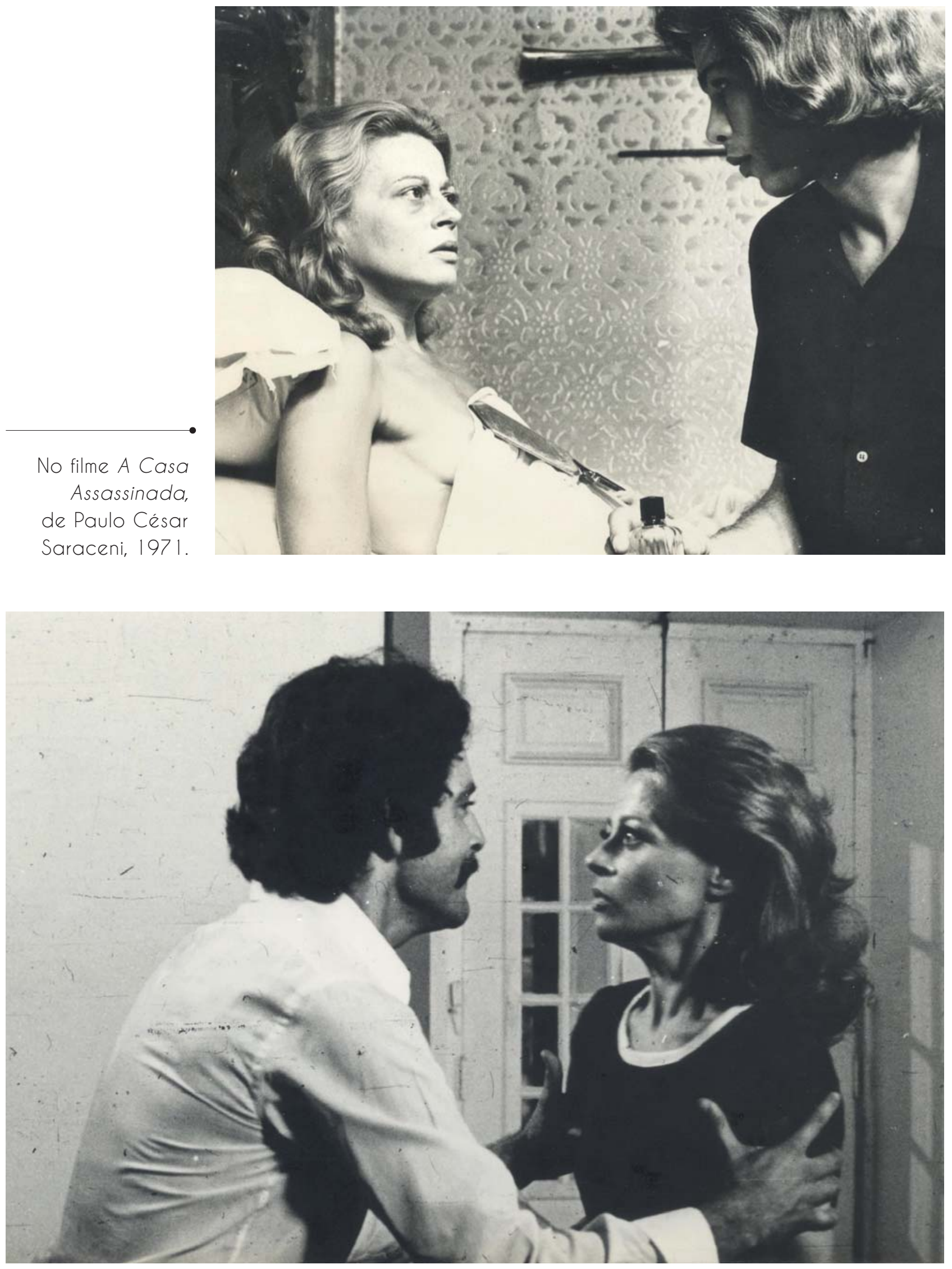

Com Cláudio Marzo em Capitão Bandeira contra o Dr. Moura Brasil, de Antônio Calmon, 1971. 


\section{rebeca}

ano 2 número 4

Trintignant no

filme A Verdade

Proibida (Défense Trintignant, 1973.

\section{de Savoir),
de Nadine \\ de Savoir),
de Nadine}
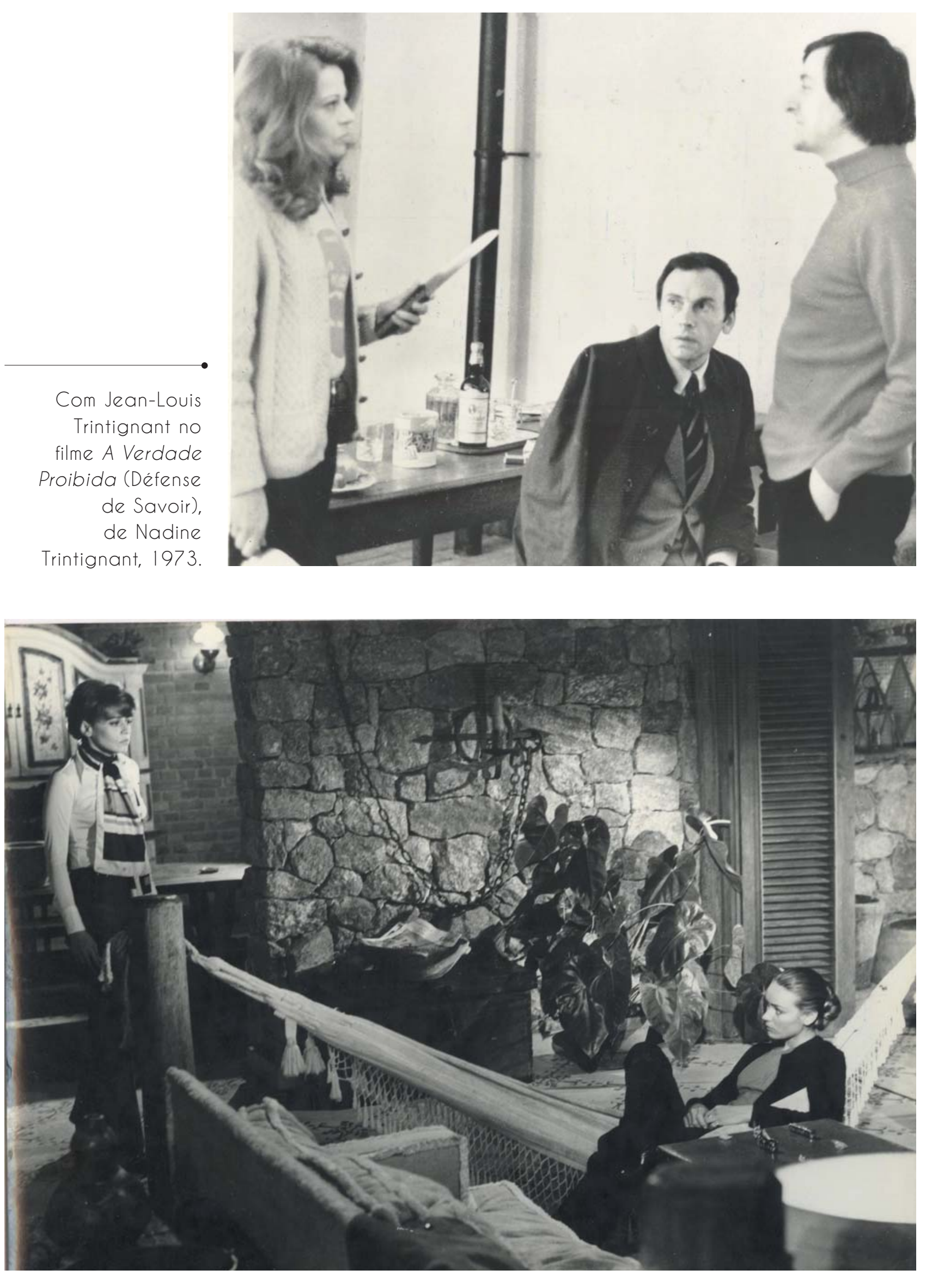


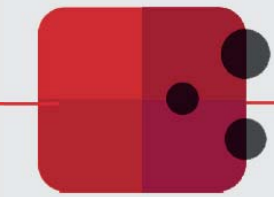

ano 2 número 4

Fora de

Quadro

Na Boca do Mundo, de Antônio Pitanga, 1978.
Norma Bengell, um dossiê fotográfico

Carlos Eduardo Pereira

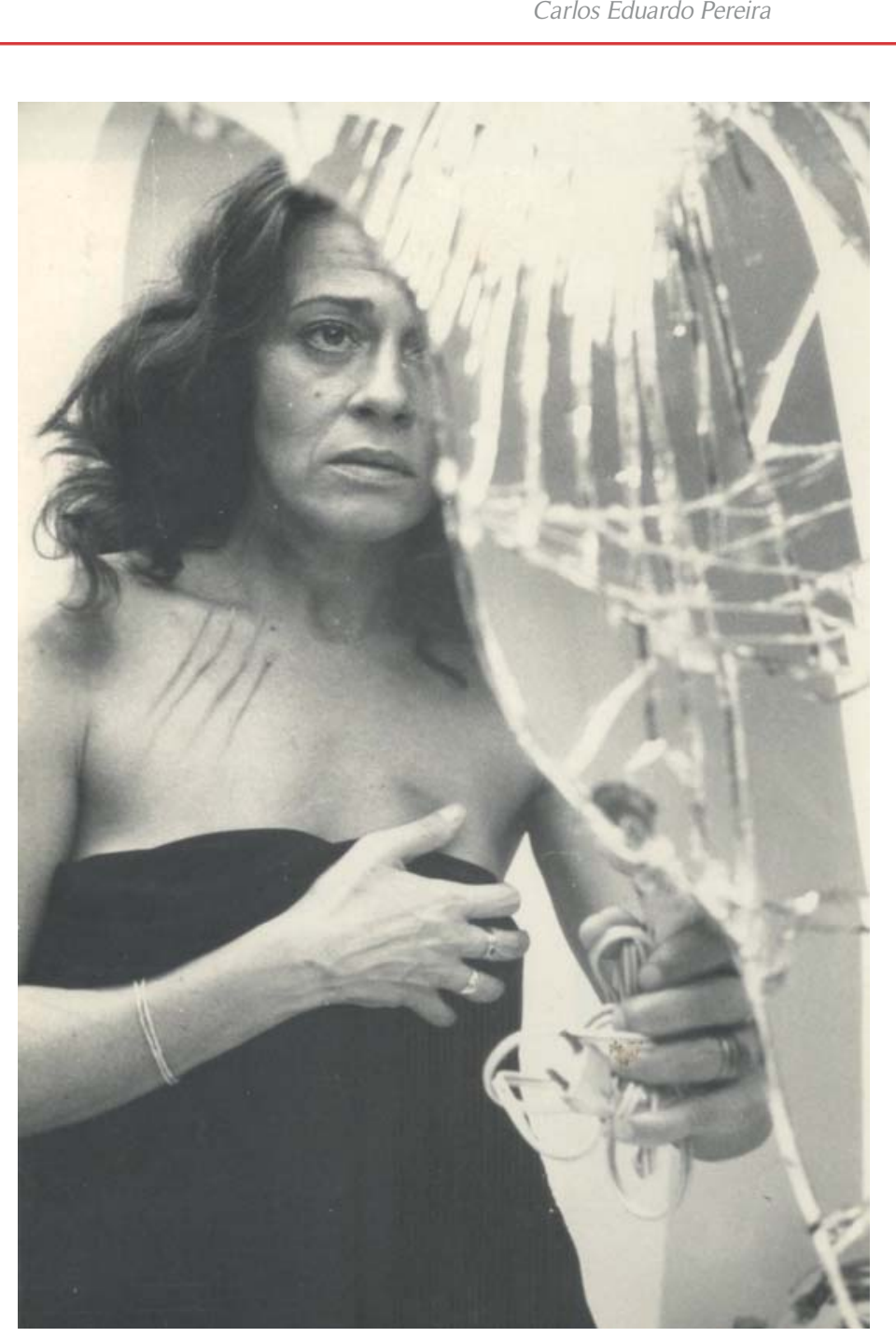

Calmon, 1976.
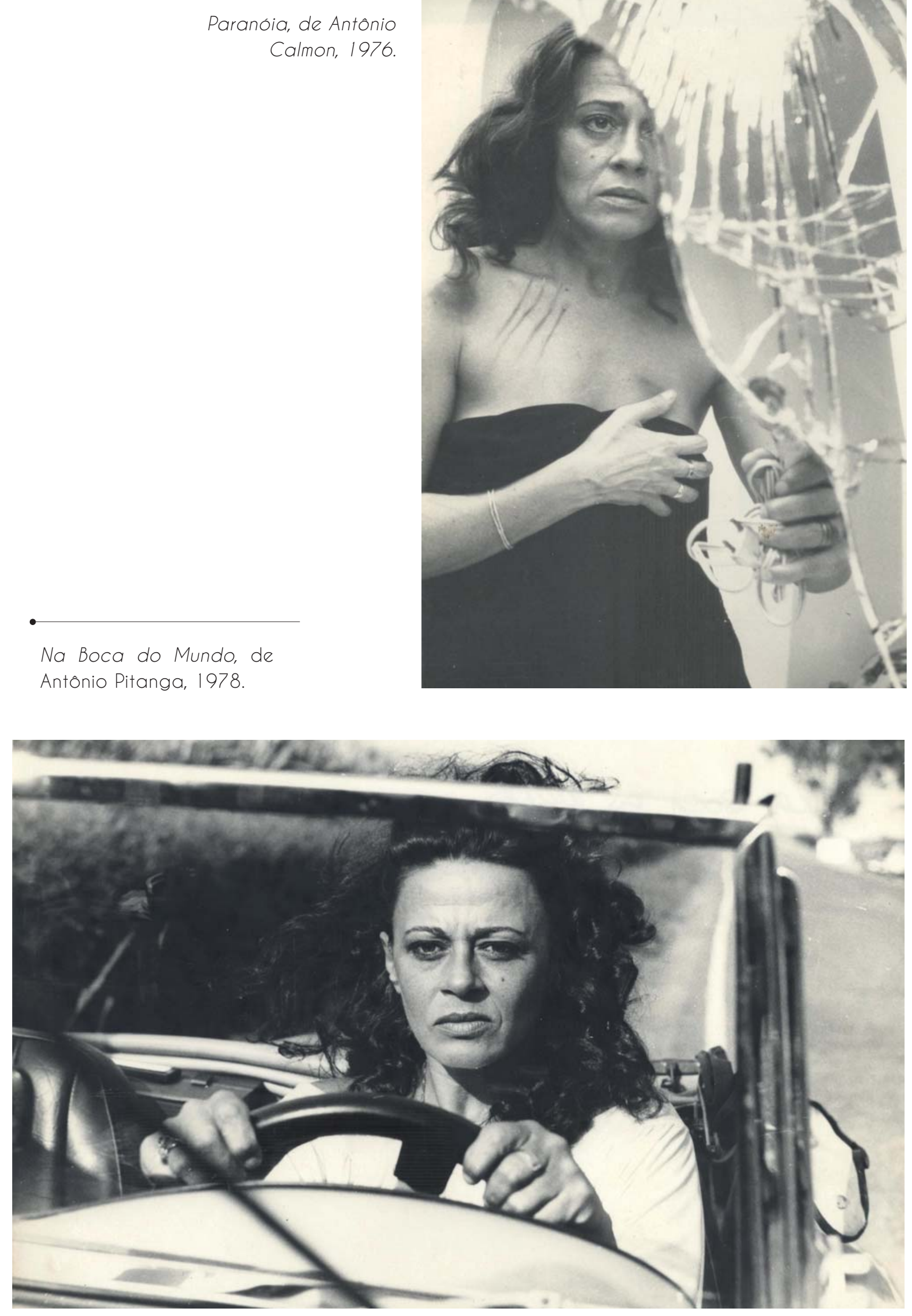


\section{rebeca}

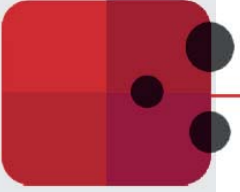

ano 2 número 4

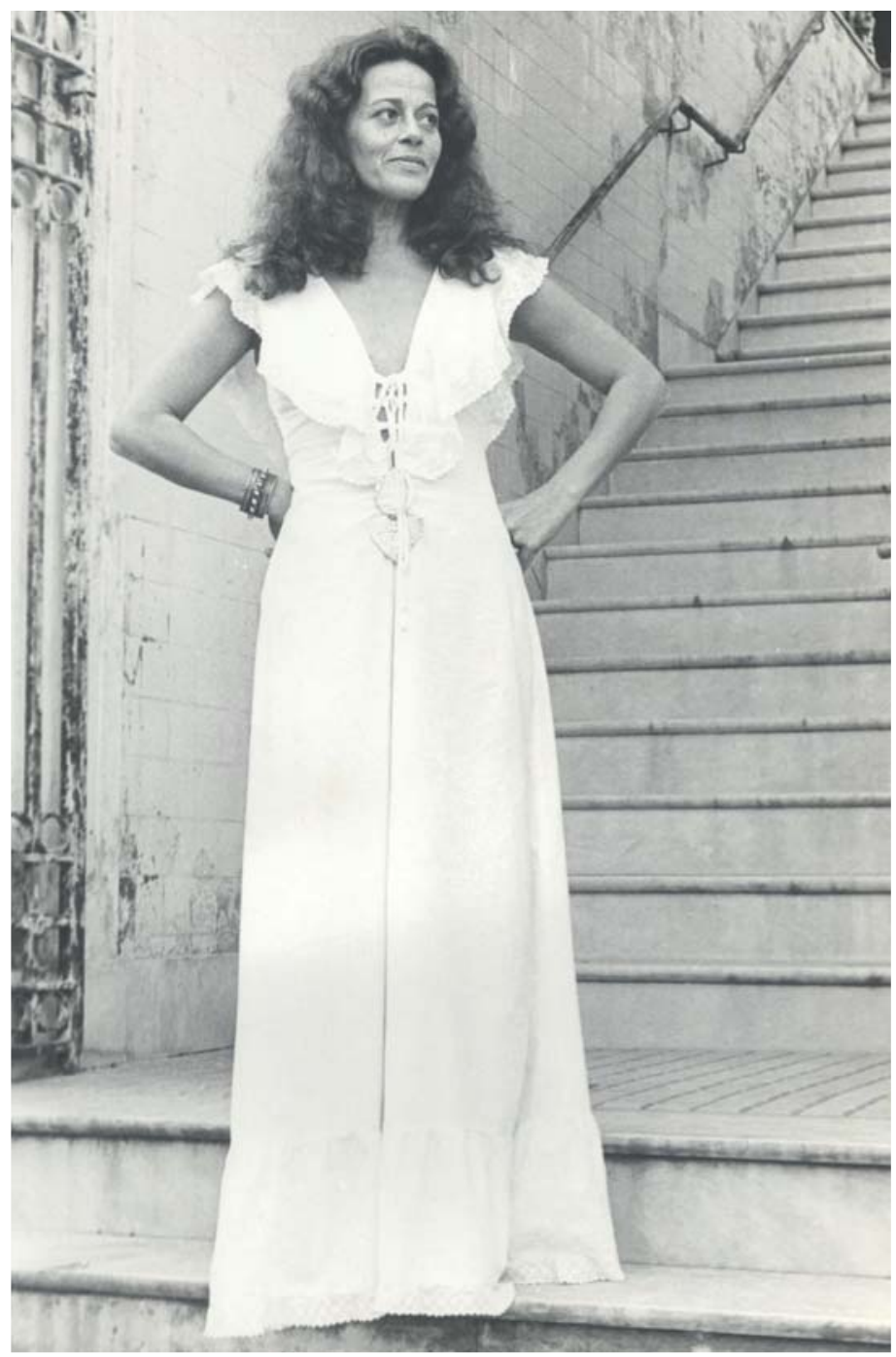

Abismu, de Rogério

Sganzerla, 1978.

Com Cristina Pereira, Myrian Muniz e Ary Fontoura no filme Mar de Rosas, de Ana Carolina, 1978.

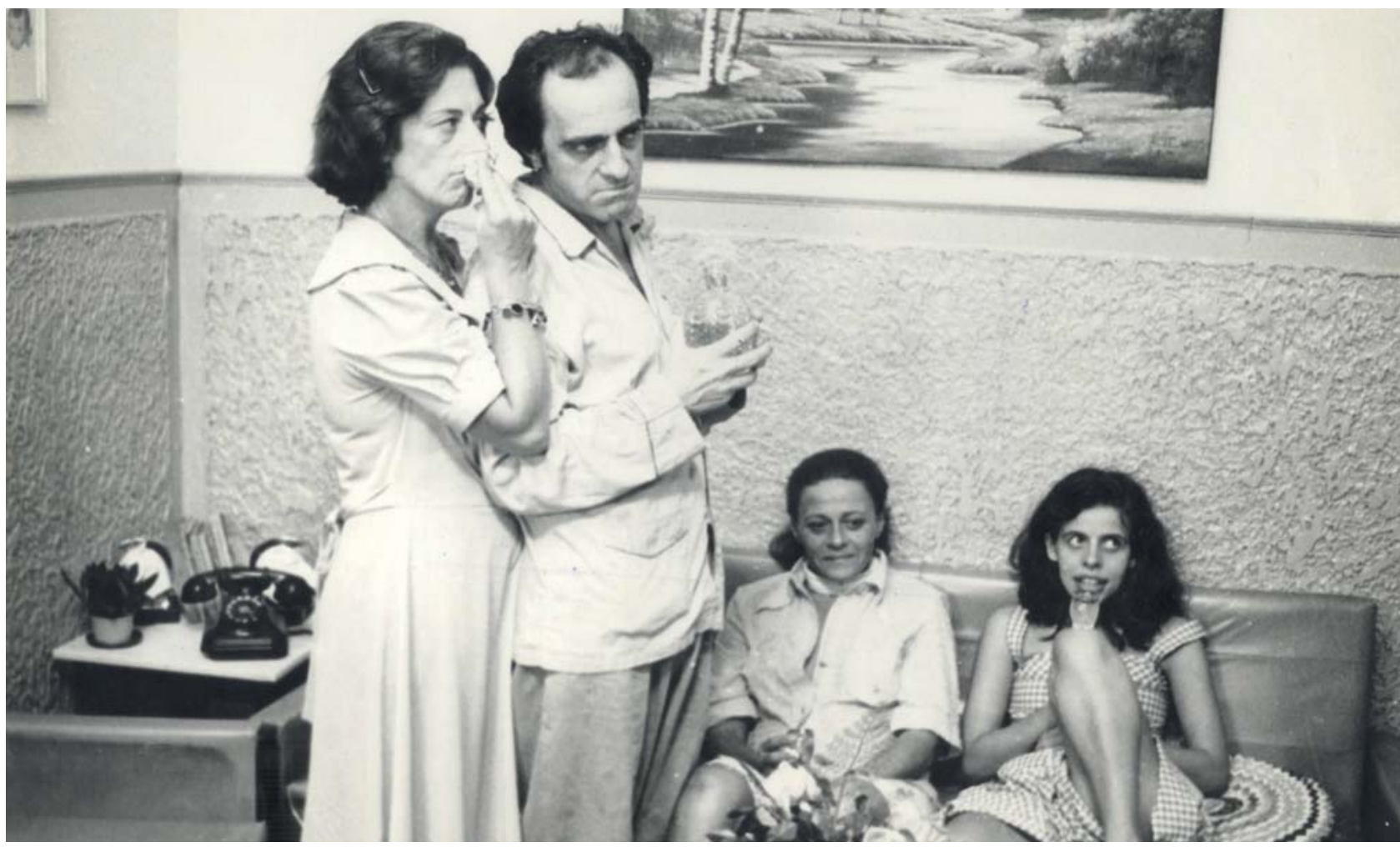




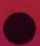

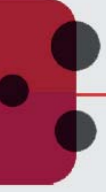

ano 2 número 4

Fora de

Quadro

No filme A ldade da

Terra, de Clauber Rocha, 1980.
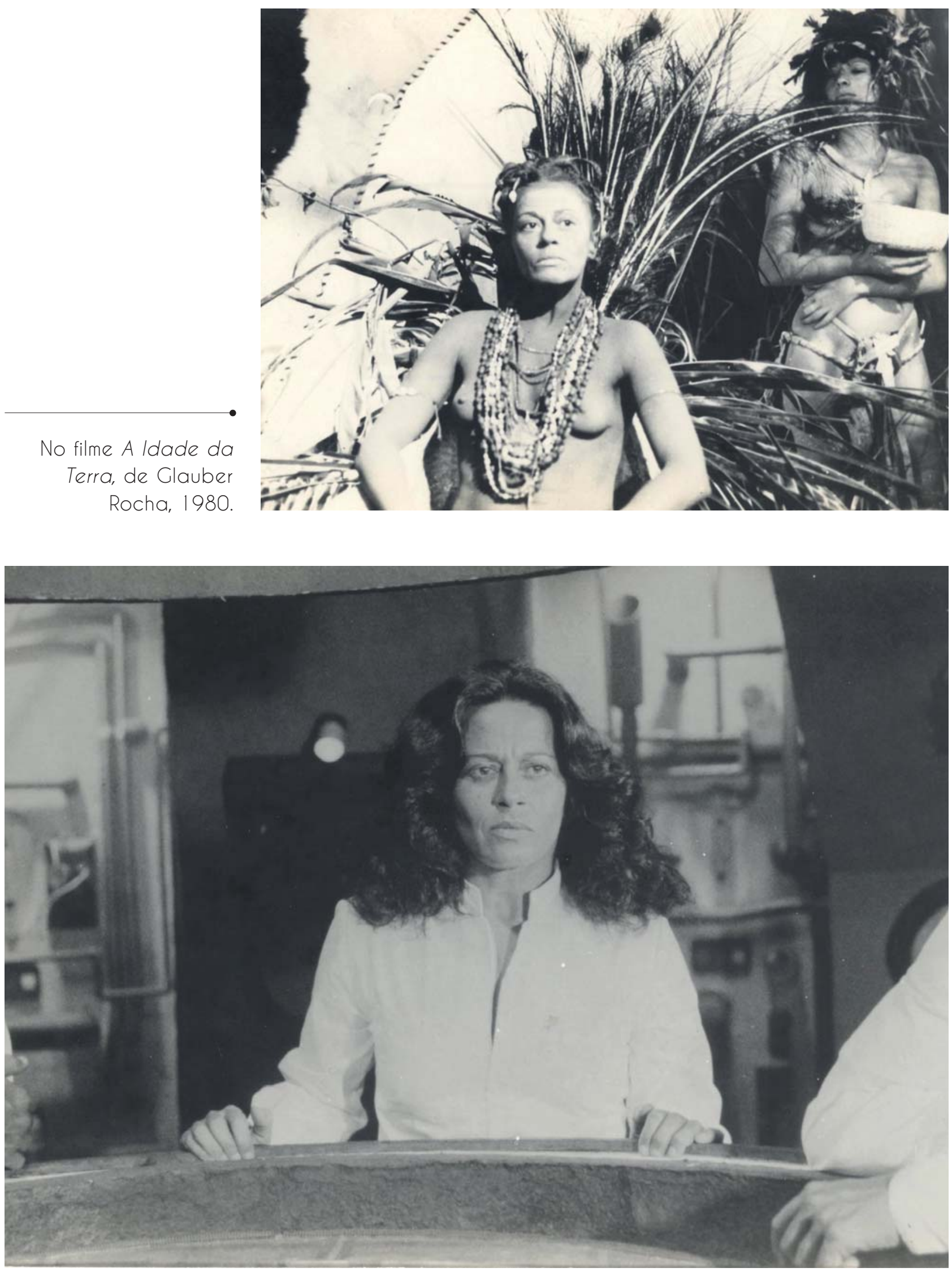

Em um dos raríssimos filmes de ficção científica do 


\section{rebeca}

ano 2 número 4
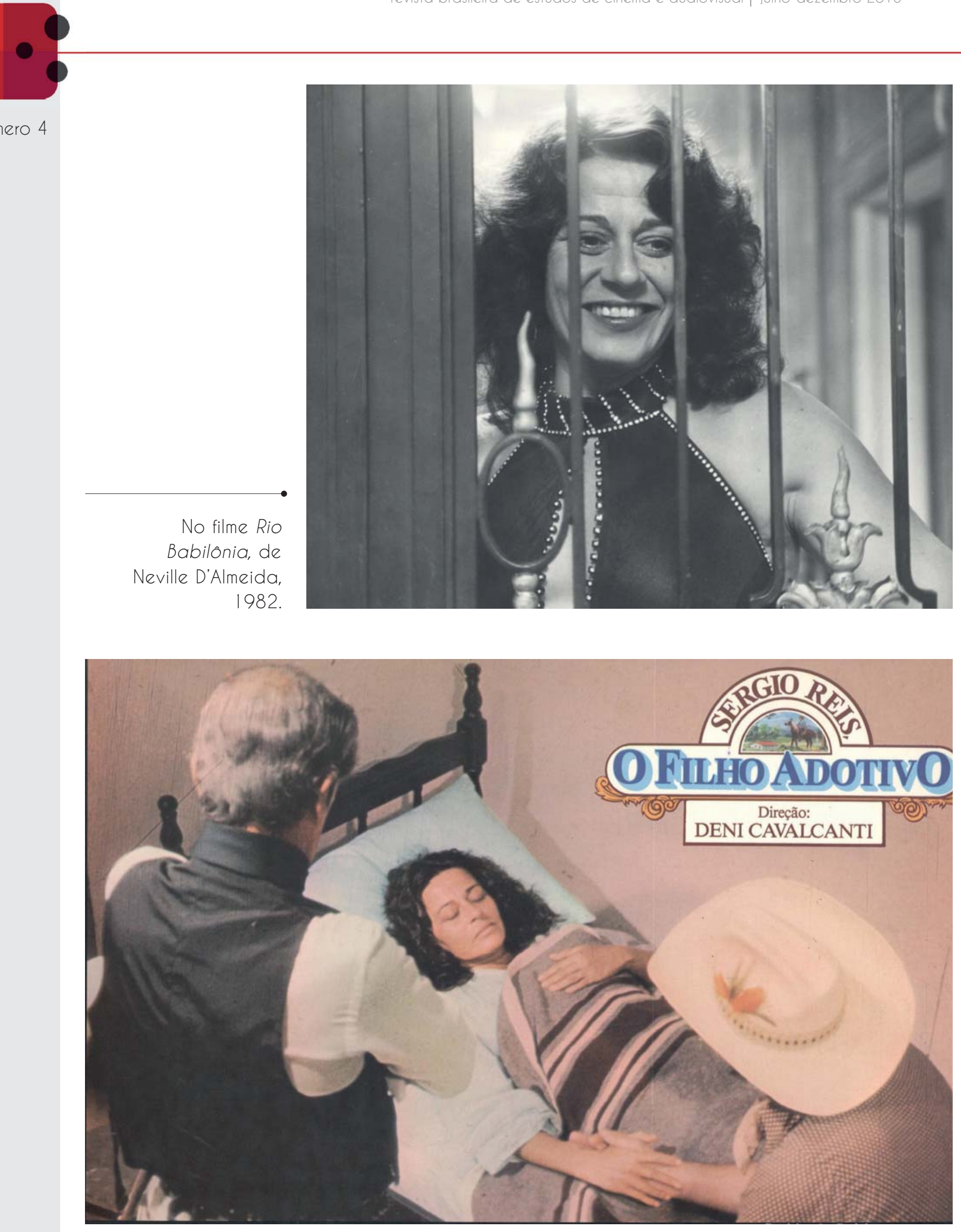

Em participação especial no filme $\bigcirc$ Filho Adotivo, de Deni Cavalcanti, 1984. 


\section{rebeca}

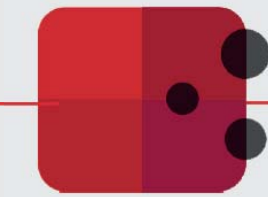

ano 2 número 4

Fora de

Quadro

Norma Bengell e

Guilherme Fontes

se encontram nas telas no filme

A Cor do seu destino, de Jorge

Durán, 1986.
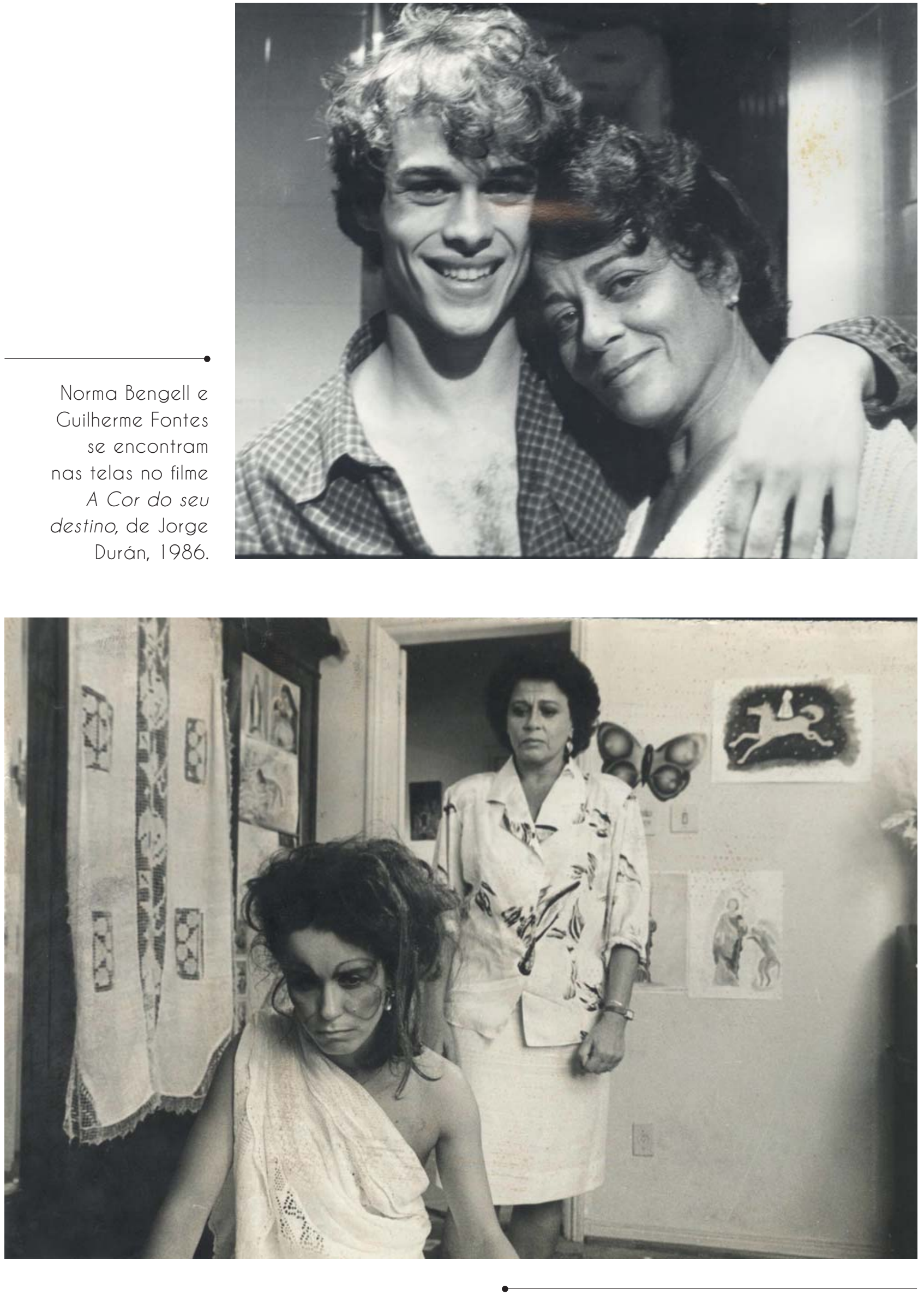


\section{rebeca}

○

ano 2 número 4

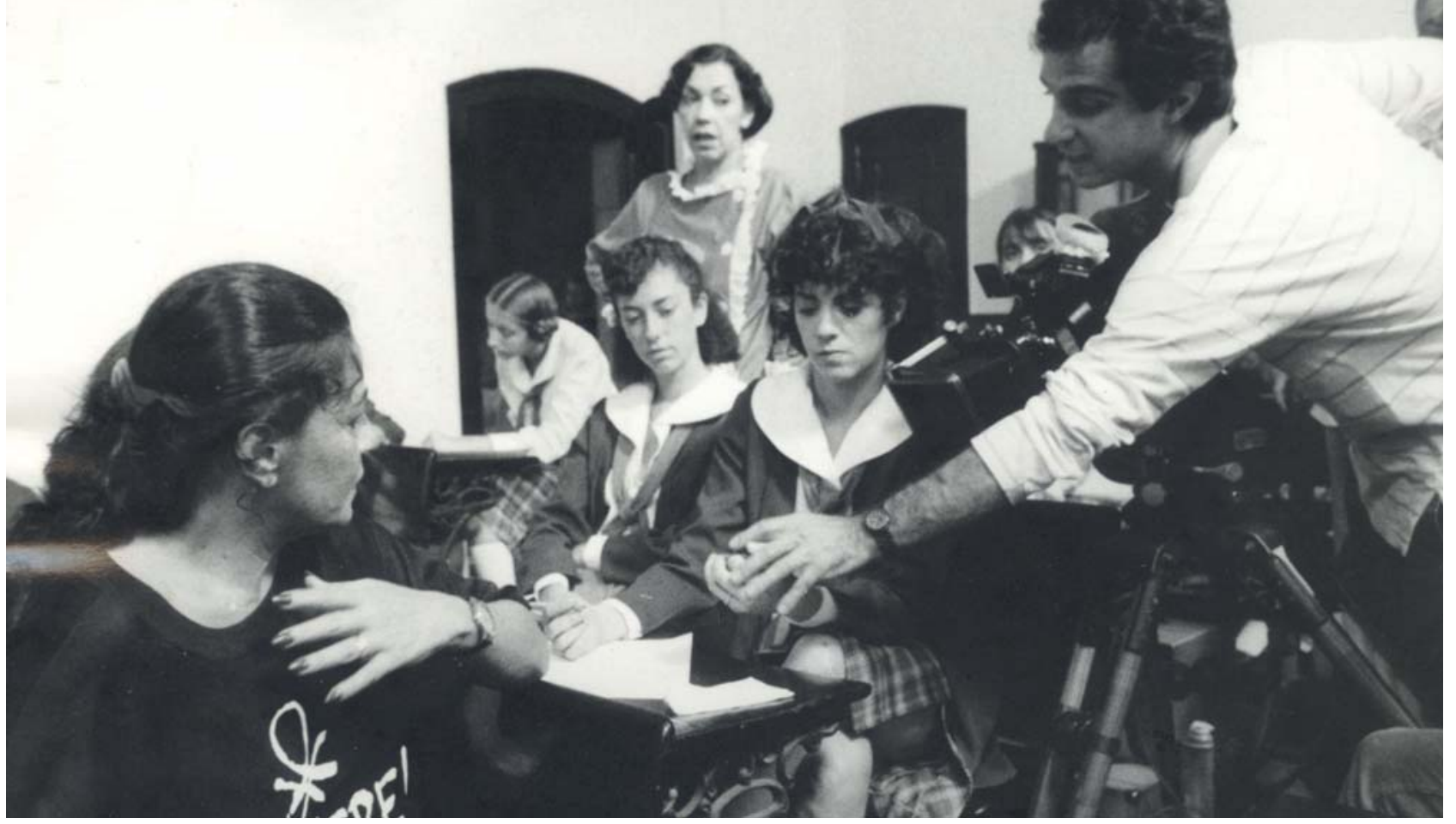

Nas filmagens de

Eternamente Pagu, 1988.

294

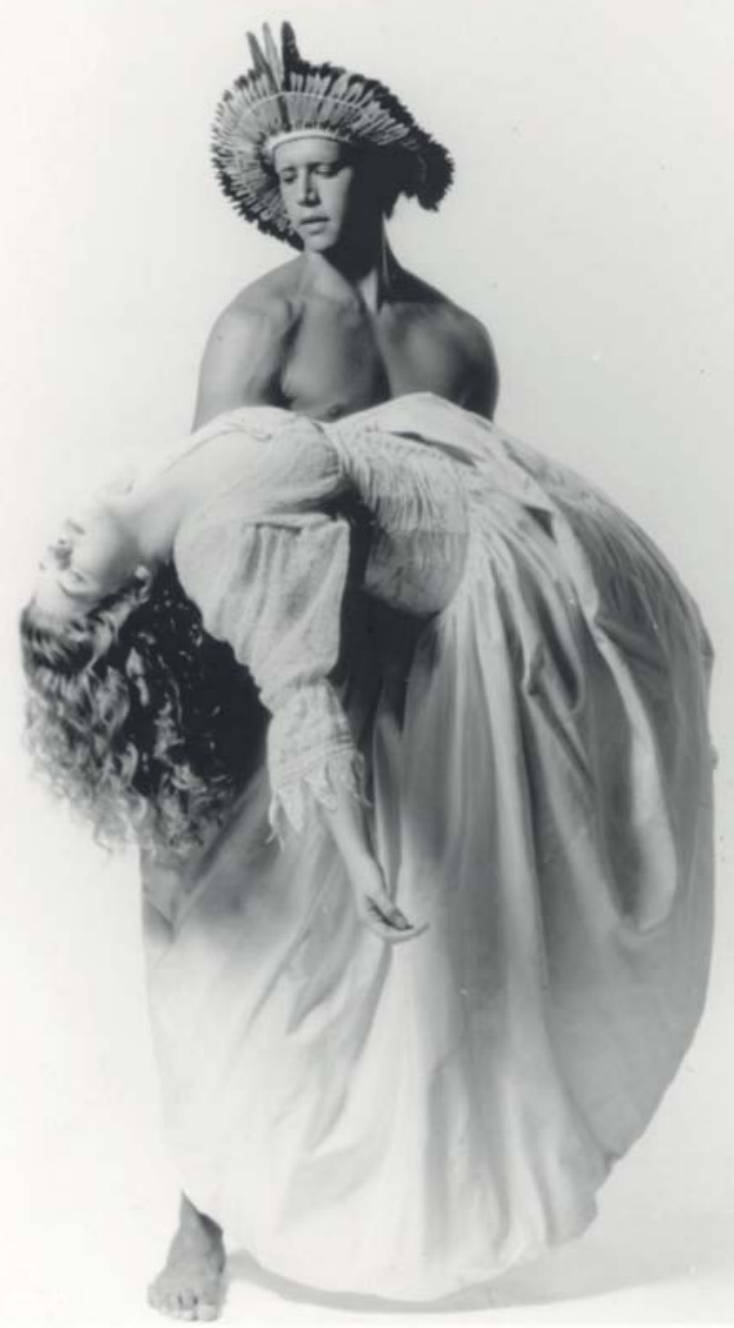

Márcio Garcia e Tatiana Issa em $\bigcirc$ Guarani, último filme dirigido por Norma Bengell, 1996. 


\section{Filmografia}

ano 2 número 4

Fora de

\section{Domo atriz}

1. O Homem do Sputinik de Carlos Manga. Brasil, 1959.

2. Conceição de Hélio Souto. Brasil, 1960.

3. Sócio de Alcova (The sleeping partner) de George H Cahan. Brasil/EUA/Argentina, 1961.

4. Mulheres e Milhões de Jorge Ileli. Brasil, 1961.

5. O Pagador de Promessas de Anselmo Duarte. Brasil, 1962.

6. Os Cafajestes de Ruy Guerra. Brasil, 1962.

7. O Mafioso (Il Mafioso) de Alberto Lattuada. Itália, 1962.

8. I Cuori Infranti no epísódio E Vissero Felice de Gianni Puccini. Itália, 1963.

9. La Ballata dei Mariti de Frabrizio Taglioni. Itália, 1963.

10. La Costanza della Ragione de Pasquale Festa Campanile. Itália, 1964.

11. Noite Vazia de Walter Hugo Khouri. Brasil, 1964.

12. Il Mito de Adimaro Sala. Itália, 1965.

13. O Planeta dos vampiros (Terrore nello spazio) de Mario Bava. Itália/Espanha, 1965.

14. Vigarice à Italiana (Una Bella Grinta) de Giuliano Montaldo. Itália, 1965.

15. O Homem de Toledo (L’Uomo di Toledo) de Eugenio Martín. Itália/Espanha/Alemanha Ocidental, 1965.

16. As Cariocas de Fernando de Barros. Brasil, 1966.

17. Os Crueis (I Crudeli) de Sergio Corbucci. Itália/Espanha, 1967.

18. Mar Corrente de Luiz Paulino dos Santos. Brasil, 1967.

19. A Espiã que entrou em fria de Sanin Cherques. Brasil, 1967.

20. Antes, o verão de Gerson Tavares. Brasil, 1968. 
21. Fedra West de Joaquín Luis Romero Marchent. Espanha/Itália, 1968.

22. Desesperato de Sérgio Bernardes Filho. Brasil, 1968.

23. Edu, coração de ouro de Domingos de Oliveira. Brasil, 1968.

24. Juventude e ternura de Aurélio Teixeira. Brasil, 1968.

25. O Anjo Nasceu de Júlio Bressane. Brasil, 1969.

26. Verão de fogo (OSS 117 prend des vacances) de Pierre Kalfon. França/Brasil/Itália, 1970.

27. Palácio dos anjos de Walter Hugo Khouri. Brasil/França, 1970.

28. Os Deuses e os Mortos de Ruy Guerra. Brasil, 1970.

29. Paixão na Praia de Alfredo Sternheim. Brasil, 1971.

30. O Capitão Bandeira contra o Dr. Moura Brasil de Antônio Calmon. Brasil, 1971.

31. As Confissões do Frei Abóbora de Braz Chediak. Brasil, 1971.

32. A Casa Assassinada de Paulo César Saraceni. Brasil, 1971.

33. Os sóis da Ilha de Páscoa (Les Soleis de l'Île de Pâques) de Pierre Kast. França/Brasil/Chile, 1972.

34. O Demiurgo de Jorge Mautner. Brasil, 1972.

35. A Verdade Proibida (Défense de Savoir) de Nadine Trintignant. França, 1973.

36. Le Soleil de Palicorna de Philippe Joulia. França, 1974 (filme para televisão).

37. Assim era a Atlântida de Carlos Manga. Brasil, 1974.

38. Une vieille maîtresse de Jacques Trébouta. França, 1975 (filme para televisão).

39. Paranoia de Antônio Calmon. Brasil, 1976.

40. Abismu de Rogério Sganzerla. Brasil, 1978. Também foi produtora do filme.

41. Na Boca do Mundo de Antônio Pitanga. Brasil, 1978.

42. Mar de Rosas de Ana Carolina Teixeira Soares. Brasil, 1978.

43. A Idade da Terra de Glauber Rocha. Brasil, 1980. 
44. Eros, o Deus do Amor de Walter Hugo Khouri. Brasil, 1981.

45. Abrigo Nuclear de Roberto Pires. Brasil, 1981.

46. Rio Babilônia de Neville D’Almeida. Brasil, 1982.

47. Tabu de Júlio Bressane. Brasil, 1982.

48. Tensão no Rio de Gustavo Dahl. Brasil, 1984.

49. Filho adotivo de Deni Cavalcanti. Brasil, 1984.

50. Fonte da Saudade de Marco Altberg. Brasil, 1985.

51. A Cor do seu destino de Jorge Durán. Brasil, 1986.

52. Running out the luck de Julien Temple. EUA, 1987.

53. Eternamente Pagu de Norma Bengell. Brasil, 1988.

54. Vagas para moças de fino trato de Paulo Thiago. Brasil, 1993.

\section{E. Como diretora}

1. Maria Gladys, uma atriz brasileira. Curta metragem. Brasil, 1979.

2. Maria da Penha. Curta. Brasil, 1980.

3. Barca de lansã. Curta. Brasil, 1980.

4. A Voz Humana. Video independente, onde também é atriz e produtora, com texto de Jean Cocteau. Brasil, 1982.

5. Eternamente Pagu. Brasil, 1987. Também foi roteirista.

6. O Guarani. Brasil, 1996. Também produtora executiva.

7. Infinitivamente Guiomar Novaes. Curta metragem documentário. Brasil, 2003.

8. Antonietta Rudge - O êxtase em movimento. Documentário. Brasil, 2004.

9. Magda Tagliaferro - a vida dentro de um piano. Documentário. Brasil, 2004. 


\section{Referências}

Arquivo Cinemateca Do Mam. Norma Bengell. Rio de Janeiro. Cinemateca do MAM. s. p. Eternelle Norma... s. a., s. l., s. d.

BENGELL, Norma. Filmografia. Rio de Janeiro, s.d. (Pertencente ao acervo da Cinemateca do MAM).

FLAi CinEMATOGRÁFICA LTDA. Eternamente Pagu (Press release). Rio de Janeiro: Flai Cinematográfica Ltda. 1987. 22p.

GARCIA, Jorge Edson. Biofilmografia. Rio de Janeiro. EMBRAFILME. 1984. 4p.

SOARES, André. Controversies: Groundbreaking Brazilian Actress Norma Bengell. EUA: Alt Film Guide. 09/10/2013. Disponível em http://www.altfg.com/blog/movie/norma-bengellguarani-lesbian-character/ 